\title{
FORMAL EXPERIMENTATION AS SOCIAL COMMITMENT: IRISH TRAVELLER WOMEN'S REPRESENTATIONS IN LITERATURE AND ON SCREEN
}

\author{
Melania Terrazas \\ University of La Rioja
}

\begin{abstract}
On 1 March 2017, former Taoiseach Enda Kenny announced formal recognition of Irish Travellers' unique heritage, culture and identity by the state. This fact triggered my interest in exploring the important cultural questions surrounding Irish travellers and investigating their (mis)representation in the fields of literature and film documentary, and its effects. The aim of this essay is double: first, to focus on the role of formal innovation in representations of Irish Traveller women in examples of contemporary Irish fiction, and its consequences, because their authors use a wide range of formal devices to merge the issues of gender and Irish Travellers' lives and conditions; second, to contextualize their work by comparison with a selection of documentary films featuring Irish Traveller women. The essay will facilitate some reflections on the complexities of their representation in literature and on screen.
\end{abstract}

KEYwORDs: Formal innovation, ethics, Irish travellers, gender, Irish literature, Irish theatre, film documentary.

\section{EXPERIMENTACIÓN FORMAL COMO COMPROMISO SOCIAL: REPRESENTACIONES DE LAS MUJERES NÓMADAS IRLANDESAS EN LA LITERATURA Y EL CINE}

\section{RESUMEN}

El 1 de marzo de 2017, el anterior Primer Ministro irlandés Enda Kenny anunció el reconocimiento oficial de la herencia, cultura e identidad únicas de los nómadas irlandeses por parte del Estado. Este hecho suscitó mi interés por profundizar en algunas realidades culturales relevantes en torno a los nómadas irlandeses y su representación (y malinterpretación) en la literatura y el documental fílmico, así como sus efectos. Este ensayo persigue un doble objetivo: en primer lugar, analizar el papel que desarrolla la innovación formal en las representaciones de las mujeres nómadas irlandesas en algunos ejemplos de la ficción irlandesa contemporánea, y sus consecuencias, ya que sus autores utilizan una amplia gama de recursos formales para fusionar cuestiones de género y las condiciones en las que viven los nómadas irlanseses. En segundo lugar, contextualizar dichas obras literarias mediante su comparación con una selección de documentales protagonizados a su vez por nómadas irlandesas. El ensayo propone varias reflexiones acerca de las complejidades de su representación en la literatura y en la gran pantalla.

Palabras Clave: innovación formal, ética, nómadas irlandeses, género, literatura irlandesa, teatro irlandés, documental fílmico.

DOI: https://doi.org/10.25145/j.recaesin.2019.79.10

Revista Canaria de Estudios Ingleses, 79; November 2019, pp. 161-180; ISSN: e-2530-8335 


\section{INTRODUCTION}

This essay was inspired by former Taoiseach Enda Kenny's announcement of the formal recognition of Irish Travellers' unique heritage, culture and identity by the state on 1 March 2017. This historic announcement meant that a person could identify as both Irish and Traveller. When asked how "recognition of Traveller ethnicity" would benefit the community, Bernard Joyce, director of the Irish Traveller Movement, spoke of experiences of discrimination "several times a day" (qtd. in Holland 2016b, n.p.). Travellers also internalize shame early, "contributing to high levels of depression, ill-health, low educational attainment, unemployment rates of up to 80 per cent and a suicide rate six times that of the settled community" (qtd. in Holland 2016b, n.p.). But who are these Irish Travellers and why are they discriminated against? In Mícheál Ó hAodha’s words, "Irish Travellers are a minority who have lived on the margins of mainstream Irish society for many centuries" (1):

It is estimated that there are at least 36000 Travellers living in the Republic of Ireland with a further 6000 in Northern Ireland" [...]. They are distinct from the surrounding population due to a range of differing cultural attributes. These include family structure, language, employment patterns and a traditional preference for nomadism or mobility as is inherent in the very ascription they attach to their community [...]. These attributes [have] aided the cohesiveness and survival of this marginal community and its culture in the face of what in recent decades, at least, has frequently been a hostile majority or settled community. (1; emphasis is mine).

These facts, together with Enda Kenny's announcement, triggered my interest in exploring the important cultural questions surrounding Irish travellers and investigating their (mis)representation in the fields of literature and film documentary, and its effects. ${ }^{1}$

Discrimination against Irish Travellers is manifest in literature and thus, as Jose Lanters argues, "It is unsurprising that many settled Irish people are still more familiar with the stereotypes surrounding that literary construct than with the real circumstances of the lives of their fellow citizens in the Traveller community" (6). This is a construct that "frequently represent[s] the Travellers as living, literally, in another world", often "associate[ing] them with figures from -mostly Celticmythology [...] to underline both their unworldliness and their separation from the settled cultural and societal norm" (134):

In the rhetoric of late nineteenth- and early twentieth-century Irish nationalism, a utopian vision of the future was contingent on the mythical construct of a unified, heroic past - an idealized and exclusionary prehistory of the Irish "race". Foundational national myths, such as those based upon the heroic defiance of

1 The research on which this essay is based was funded by research projects REGI 2018/36, EICOD 19/18 and AOCYRC 19/23 (Vice-Rectorate for Research, University of La Rioja). 
Cuchulain, or the renewal of the nation through blood sacrifice, or the rootedness of the peasant in the land [...], which originated as efforts to emancipate the Irish from their colonial inferiority complex [...], draw a magic circle around the definition of Irish identity, often to the exclusion of a dialogue with any group or set of individuals that did not fall within its bounds. A minority group within Ireland such as the Travellers occupied a problematic position within these narratives of national identity and unity, and their representation had to be carefully "managed". Revival writers uneasily tiptoed between including the "tinkers" in their projects about Irish folk life [...], and rejecting the depiction of a way of life that, in its wildness, might reinforce ingrained British preconceptions about the drunken and unruly Irish. (141)

Pursuing this line of argument, Jose Lanters notes that most Irish "mythic narratives portraying Travellers or 'tinkers' do not perceive them as genuine human beings" (161). Travellers' life stories often comment on the way in which they are stereotyped by the settled community as dirty, dishonest, sexually promiscuous and given to excessive drinking. Moreover, Lanters continues arguing that "Travellers are often discriminated against purely on the basis of how they look and sound, there is a self-consciousness in their stories about ways in which they differ from settled people" (193-194). This may explain why they "often consciously try not to look like Travellers when they go out for fear of not being admitted to a pub or club" (194). Many studies present Travellers as vulnerable subjects and reinforce the notion that they are quaint and exotic if not actually in need of correction.

In the first decade of the twenty-first century, several Irish women writers addressed feminist considerations in their work in order to transform ideas of what Ireland was, is, or could be, and their formal experimentation in various genres proved crucial to this end. In By the Bog of Cats (2002), for example, playwright Marina Carr reinvents Euripides' Medea in an attempt to explore the position of women in Irish society after independence. Carr takes the figure of the strong woman embodied by the fearsome Medea and develops it into something to be celebrated. Her Hester Swane, a Traveller, is a marginalized figure corresponding to the barbarian Medea. The unfamiliar Irish midlands dialect and the landscape of the bog also play a significant part in interpreting the relevance of the Greek model to the Irish retelling, for the bog can be read as a mythical space with a supernatural undertone that makes By the Bog of Cats clearly Irish. Carr uses the mythical method as well as her knowledge of traditional Irish folklore and fantasy to show how her protagonist struggles with questions of identity as she raises her daughter Josie in an Ireland of the recent past. The mythical method is also used to look at violence perpetrated against these two Traveller women and to portray the tragic and traumatic consequences of such violence.

Claire Keegan also uses female Traveller protagonists to reject the Mother Ireland image of compassion and suffering, and to represent the reality of women's life in modern rural Ireland. In "The Forester's Daughter", in her second collection of stories, Walk the Blue Fields (2007), she does so with Martha and her daughter Victoria. Keegan not only recovers the storytelling tradition of rural Ireland and its mythical narratives - seeming to doubt the ability of the realist short story form to 
portray intimate female conflicts and dilemmas- but also uses of a large repertoire of rhetorical strategies of the satirical apparatus, as we shall see, to both tackle Traveller women's issues and achieve her unique tone.

The Irish Traveller women depicted by these two well-known writers have very different traits, but they share similar origins and, unfortunately, similar unworldliness and feelings of separation from the settled cultural and societal norm. The figure of the Traveller is significant to their work, which, first, opens up an ethical and political inquiry regarding Irish Travellers women's lives, social position, sense of motherhood, sexuality, and marginalization, since they represent a step backwards from the accomplishment of Irish Traveller women's self-actualization; and, second, disturbs complacency.

In the second decade of the twenty-first century, the Irish Traveller woman as a literary figure has been appropriated by some Irish writers: Rosaleen McDonagh in her play Mainstream (2016) and Donal Ryan in his novel All We Shall Know (2016). The former presents the story of four disabled characters, three Travellers who are old friends and a settled journalist who wishes to make a documentary about their lives; the latter features Melody, a settled, married teacher who falls pregnant by Martin Toppy, a Traveller student 13 years her junior. Both McDonagh and Ryan use satirical methods of rhetorical inquiry to undermine many stereotypes associated with the Traveller community in general, with a special attention to Irish Traveller women. There are some differences in their approach to the issue, since McDonagh is a disabled Traveller who writes from her feminist perspective, whereas Ryan is a man and a member of the settled community. They nevertheless both use the satirical mode to undertake an implicit criticism of society's prejudices against Irish Travellers in general, and Irish Traveller women in particular.

The aim of this essay is double: first, to focus on the role of formal innovation in representations of Irish Traveller women in examples of contemporary Irish fiction, and its effects (the four writers identified above use a wide range of formal devices to merge the issues of gender and Irish Travellers' lives and conditions); second, to contextualize their work by comparison with a selection of documentary films featuring Irish Traveller women -Perry Ogden's Pavee Lackeen (2005), Jason Byrne's Rosaleen McDonagh: My Story (2009), and Kim Bartley's I Am Traveller (2016). The essay will explore not only how Irish literature and documentary film engage with tradition regarding Travellers, but also the ways in which traditions are reinvented, subverted, and repositioned, facilitating some thought-provoking reflections on the complexities of their representation in literature and on screen. In this way, I attempt to provide new insights into Jose Lanters' claim that Irish Travellers continue struggling "to be acknowledged as being both Irish and different" (206).

\section{IRISH TRAVELLER WOMEN IN LITERATURE}

Carr's By the Bog of Cats revolves around 40-year-old Hester, who has been abandoned by her younger husband, Carthage, in order to marry a wealthy girl half her age. Hester and her daughter Josie live in a caravan by the eponymous Bog of 
Cats and must leave before the marriage because Carthage wants a better life for their daughter. Hester refuses to go and tells Carthage that he will never see their daughter again if he goes through with his wedding. Later, she sets the newly-weds' house on fire. Influenced by the malefic nature of the bog, which is traditionally associated with dead matter and decay, Hester has her revenge, ultimately murdering Josie.

Through its depiction of Hester and Josie, the play shows an apparent consensus on the tinker community. Josie's grandmother tells her:

I warned him [Carthage] about that wan, Hester Swane, that she'd get her claws in, and she did, the tinker. That's what yees are, tinkers. And your poor Daddy, all he's had to put up with. [...] Why don't yees head off in that auld caravan, back to wherever yees came from, and give your poor Daddy back to me where he rightfully belongs. (279)

Hester and Josie are marginalized because they are tinkers, living apart from settled cultural and societal norms in the Irish Midlands. Imitating her grandmother, Josie presents her mother as outside Irish Catholic morality, calling her "Jezebel witch" (285). Carthage characterizes Hester in similar disparaging terms: "your drinkin' or your night roamin' [...] ya sleep in that dirty auld caravan and lave Josie alone in the house" (290).

The settled characters have an image of the Traveller community's circumstances that is based in stereotypes that are far removed from the reality of Hester and Josie. By using formal techniques, Carr confronts questions of social justice in contemporary Irish society and reveals that Irish attitudes toward the Traveller community have changed very little. The fantastical aspects of Carr's work allow her to shape tinkers to serve the imaginative requirements of her play and the purposes of her message. In a highly class-ridden society like Ireland, Carr, as a playwright, seems to feel somewhat of an outsider, a bit of a Traveller herself, because writers too are constantly judged -people always have opinions about travellers and about art. Writers often face negative receptions, and thus, like Hester the Traveller, Carr seems to feel an outsider in a way. This may be why Carr's heroine Hester has an answer for everything in the play and no one does her down.

Josie does not repudiate her mother, unlike the other characters, and learns to speak in her own voice. Josie, a modern Traveller, represents a young female voice of dissent empowered by a secure identity. Carr seems to suggest that the ascendancy of a feminine sensibility in the collective unconscious that does not conform to traditional norms or patriarchal constructions of femininity -embodied by a new generation of the Traveller community- leads directly to Hester's infanticide and subsequent suicide. The two Travellers die in the derelict Bog of Cats, they are buried in this land, thus presenting a theme that is analogous to Elliot's Wasteland, which tackles the theme of the regeneration and fertility of the past. Carr presents regeneration as painful because the present cannot measure up to an idealised past: Hester's experiences become a source of distress when she considers that her present life with her daughter is one of great personal and cultural suffering. Josie provides a revelation or regeneration of the figure of the Traveller in Carr's play. 
Our second object of analysis is Keegan's “The Forester's Daughter”, which narrates the story of Martha, the eponymous forester's daughter who marries Victor Deegan, an egotistic, emotionally stunted man she does not love in the hope that she will come to love him. One day, Martha buys roses from a Traveller with whom, unbeknown to Deegan, she has a pleasurable sexual encounter. This extramarital liaison leaves Martha pregnant with her daughter Victoria, who is a genuine tinker because Martha is herself a storyteller of tinker blood. As the story comes to end, Martha has her revenge on Deegan for focusing on their fields, and ignoring and overshadowing her and her daughter by making public the fact that Victoria (note her name) is not his daughter, and even though the reader sees it coming and realizes its inevitability, he is still a little surprised when it happens.

Martha wishes Deegan would take an interest in her and her family's feelings. She wishes he would treat her like a woman, as the Traveller had, but he is emotionally empty. She also wants to find a job and a place of her own. However, as usual in rural Ireland, pregnancy binds her to the domestic sphere. As Eve Patten argues, in "the so-called 'city-girl' novels [...] from authors such as Patricia Scanlan [...] and Sheila O'Flanagan [...], which frequently feature independent young Irish women detaching themselves from traditional family structures in order to access and enjoy the social and consumerist cityscape of 'Celtic Tiger' Dublin” (267). Keegan's Martha is determined to leave her world behind with the money she has "not put on the table". Like Carr's Hester, Martha refuses to conform to the Mother Ireland image of female compassion and suffering. Unlike Carr, however, Keegan presents the force of the mother-daughter link as ultimately unfulfilling. However, unlike Hester, Martha's tinker heritage does not prevent her from escaping or make her unwilling to do so; it is her love for her rural world and the strictures of Victor Deegan's patriarchal order that influence her decision not to walk away. She remains trapped in the blue fields.

Hester feels that escape is only possible through death and so kills Josie, and later kills herself. Eve Patten notes a similarity to Keegan's Martha (267). However, as Ní Dhuibhne rightly argues, Martha "is not really much of a martyr [like Hester]. On the contrary, she is subversive, rebellious, even something of a feminist" (2008, n.p.). She develops effective strategies to achieve equality with Deegan, or at least to ameliorate the effects of inequality in their daily communal life. For example, she puts aside some money to go the cinema in Dublin, rather than using it to buy food for the family. Here Keegan not only throws into relief the dissenting position of many women in rural Ireland, but also denounces their tragic entrenched subordination, financial dependence, and relegation to the private sphere. As Heather Ingman claims, in her "marriage of necessity" (168), Martha, like Hester, contributes to the emotional and tragic impact of the story because, as Jose Lanters argues, she struggles "with questions of identity, fate and self-determination" (149). Martha and Hester are unemployed, serve their husbands and raise their children, have no economic independence -but want it- and live in a heteronormative, patriarchal caged family whose excessive constraints go against nature and render it dysfunctional, characterized by mental disorders or maladapted behaviours.

Keegan's witty discourse, recovery of the rural Irish storytelling tradition, and rejection of the realistic short story form serve to illustrate women's intimate 
dilemmas and conflicts. In unearthing all these social malfunctions in innovative ways, Keegan shows the path to achieving her characters' psychological and social fulfilment. Keegan, like Carr, is very well acquainted with the tinkers' predicament, and uses her familiarity with Irish folklore, the storytelling tradition, and the surreal to give form and narrative structure to the "The Forester's Daughter". In fact, Martha herself tells a story to her small community, the story of Mona which mirrors her own and is very telling for other reasons besides the formal:

"They were married [...]. One day [...] a traveller, a stranger [...] was selling roses [...]. She bought every last one [...]. When she went near him, her hand touched his throat and then his thumb came up and stroke her lips. His hands were soft compared to Nowlan's [...]". Deegan cannot stand it anymore [...]. As soon as he stands, the neighbours turn to look at him [...]. In his heart he has always known the girl [Victoria] was not his own. She was too strange and lovely to be his (83-86).

In her self-reflexive recounting of Mona's unfaithfulness to Nowlan, Martha draws attention to the pressure exerted by the community regarding motherhood in rural Ireland, makes a case for Travellers' rights and undermines Deegan's authority and stance in both domestic and public contexts. Keegan experiments with storytelling techniques as an indirect vehicle for sociocultural messages:

Something about the way [the story is] told tells him Martha knows he's listening. Finally, he hears his son, the simpleton, shout, 'Mammy had a boyfriend". Deegan's feet carry him down the yard. [...]. Finally, he goes in. [...]. All around her are the vacant chairs, the empty glasses. [...]. 'Are you happy now?', he says. 'After twenty years of marriage, you are finally asking'. (86-87)

In this way, Keegan not only reaffirms Martha's sense of herself, her sexuality, femininity, and identity, but also expresses her desire for freedom from patriarchal conceptions of women and their bodies. Keegan's formal experimentation and her disruption of traditional Irish thematic motives constitutes a good example of social commitment to Traveller issues and of how the contemporary Irish short story form is in a state of flux.

Like her mother, Victoria has discovered strategies of survival, yet, unlike her mother, she is fulfilled. In her daily encounters and interactions, she also reveals the importance of the links between all the characters in the story, except her mother. In this way, she becomes more tolerant and uninterested in keeping the house and the land. Victoria is Keegan's reworking of the stereotypes of the tinker literary construct and an expression of her taste for dream-like fantasy. Like Josie, Victoria refuses to repeat her mother's thwarted life, though she does not repudiate her, and she too learns to speak in her own voice. This is Keegan's narrator:

Aghowle [their house] is in flames. Deegan, in his bare feet, goes over to his wife. There are no tears [...]. Martha holds on to her daughter's hand. She thinks of her money, the salesman and all those obsolete red roses [which he bought her before their extra-marital sexual encounter]. The girl has never known such happiness; Judge [her dog] is back, that's all she cares, for now. (89-90) 
Keegan reveals Martha's subjugated world in order to assert the force of the motherdaughter link. As Anne Forgarty argues, Victoria embodies "the desperate struggle of the daughter to avoid the trap of female subjugation and the calamity of duplicating the mother's experience" (113). Unlike Martha, Victoria is self-confident and positive, strong rather than a victim. She resembles other tinker girl characters that feature in many mother-daughter stories in earlier Irish women's writing, like Josie in Marina Carr's By the Bog of Cats. Keegan speculates about social questions to criticize society. Her deployment of rhetorical devices of the satirical apparatus in "The Forester's Daughter" not only offers profound insights into such matters as unhappy unions, marital discord, familial instability, dysfunctional childhood, unfulfilled sexuality, resistance to mothering, and the crisis of gender roles, but also allows her to question tinker stereotypes and predetermined literary forms. The different voices on marriage, parenthood, the traditional links of family life, and Irish Travellers that enter into unresolved dialogue in Keegan's "The Forester's Daughter" seem to be intended to dazzle her audience.

Rosaleen McDonagh is an academic and an activist. She worked in the Pavee Point Traveller and Roma Centre for ten years, managing the Violence Against Women (VAW) programme. She has been involved in initiatives on Traveller women's issues and is regarded as a leading proponent of feminism with the Traveller community. Her play Mainstream is about four young friends with disabilities. One day, film-maker Eleanor wishes to make a documentary about their past living together. As the story evolves, their relationships and friendship become unstable.

McDonagh uses the rhetoric of satire, particularly irony, parody, and wit, to problematize the very process of writing and to deconstruct stagnant ideas about Irish Travellers, with a special attention to women. The content of satire is criticism, which may be uttered as direct rebuke or through several rhetorical devices. Following Paulson, the satirical piece depends on its capacity to be indirect and satirists achieve this indirectness by drawing upon a series of technical devices or strategies (116). Irony endows McDonagh's writing with obliqueness and indirection. Her use of verbal irony ("We seem to be in vogue at the minute -reality TV, night-time radio talk shows") implies the opposite of what is said, and depends on wit and playfulness, because there are times when the ironic implication of a particular statement resides in the use of a word in a purposefully de-contextualized situation:

Jack: Tell me about you! Why are you making a documentary? Why us? We're yesterday's story.

Eleanor: The commissioning spec wanted diversity.

Jack: We seem to be in vogue at the minute-reality TV, night-time radio talk shows, most of it makes us look like fools.

Eleanor: I'm trying to make an interesting piece of television. My documentary will have integrity and authenticity.

Jack: looks at her blankly [...]. Her documentary-it's a bit like rent-a-pavee. Why did I ever agree to do this? Tell her she can go and kiss my cojogs. [...]

Eoin: Daddy Jack. Don't go there with her, Jack. Focus her attention on the drinking [...]. They love that. A former athlete recovering -better still... a Traveller 
fein fights the demons in his head and struggles to give up the drink! You'll be such a fuckin' hero! (4-9)

Further, McDonagh's use of other satirical devices in this passage, like wit, is usually matched with an ingenious use of language that causes laughter and delight. The passage is ironic, yet its intention is not satirical, but playful. McDonagh's inventiveness is shown in the use of puns or intentional verbal incongruities, such as "rent-a-pavee" or "cojogs", and contributes to strengthening the satirical premise of indirection. Wit is an artifice employed to disguise the aggression that underlies satirical attack, making it socially acceptable. The basis of wit is distortion of the usual semantic, phonetic, or orthographic appearance of words in order to shock the reader, as we observe in the quotation above.

The next passage is another example of McDonagh's sharp description of the Traveller woman figure. Eleanor questions Mary-Anne about different stereotyped views of the Traveller community. The latter provides a view of patriarchal models within the community and reflects with irony, wit and scatology upon the triple discrimination to which she is subject as a woman, a Traveller, and disabled:

Eleanor: So you're not repressed or controlled by the family? [...].

Mary-Anne: There you go again. It's context. In any culture a woman's mistakes are rarely forgiven...

Eleanor: [...]. Traveller culture is so male. And women like you collude with that crap. Mary-Anne: And you are so liberated. In all politics - be it Traveller-be it disabled -be it gay- it's always about men. The gender stuff, the disability stuff, the Traveller stuff, the racist stuff. We're the nuisance they can't get rid of. [...]. The women's movement -that's a good example. [...]. Let's sort out sexism first. Your little issue like access or diversity we'll deal with that another day.

Eleanor: So you're trying to protect your sisters and some notion of family name. Mary-Anne: All sorts of women are caught in a compromise. It's not right. It's not fair, but at least try and understand our lives are complicated. I am a Traveller woman. What I call liberation doesn't mean turning my back on the values that I was reared with. [...]. It is the stuff that we're all trying to work out in our families and communities and relationships. A settled woman telling me I should do this is equally archaic.

Eleanor: Eoin - the gay stuff- we hear about how difficult it is for gay Traveller men. Where are the lesbians?

Mary-Anne: They're rampant. (Both women start laughing.) Female sexuality -women don't make a song and dance about it. Regardless of circumstances, people will always find each other. (34-35; emphasis is mine)

Mary-Anne wittily deconstructs a wide range of stereotypes regarding Traveller women based on a patriarchal perspective. McDonagh's use of the satirical mode, including repetition, contributes to an enhanced perception of Irish Travellers' situation. The playwright claims that stereotypes about Irish Traveller women can be false; they are not passive, but strong, yet their lack of opportunities and education 
are often genderspecific. As a disabled woman, McDonagh shows Irish Traveller women's wish to be educated and their suffering when education is denied them, as happened to her. This sort of gender-specific discrimination does not seem to go away with the passage of time, but causes great psychological damage. McDonagh defends Irish Traveller women's claims for freedom of sexual orientation and pride in their ethnicity and culture. She draws attention to Irish Traveller women's ambivalence towards such views held by Irish Traveller men and also advocates for a strong defence of the idea of sisterhood and collaboration among Traveller women. Within this context, the journalist's last words in the play demand a more respectful, informed attitude towards Irish Travellers:

Eleanor: Mary-Anne and Eoin and to some extent Jack -they celebrate their lives, their bodies, and their identity. No big spectacle. [...]. This virus of abuse has to stop somewhere. Their strength and dignity was the story. My camera went back in the bag. There was nothing to give my producer. (47)

McDonagh's parody turns to irony elsewhere to achieve indirection and to deconstruct unquestioned ideas about Irish Travellers. In doing so, the Traveller playwright reflects upon the act of filming itself, questions predetermined filmic standards, and problematizes the very process of filming Irish Travellers.

Our last object of analysis in this first section is Donal Ryan's novel All We Shall Know. The story is narrated by Melody Shee, a settled character who fails to conceive the hoped-for child with her husband Pat and falls pregnant by Martin Toppy, a Traveller boy half her age. This is the powerful opening:

Week Twelve

MarTin Toppy is the son of a famous Traveller and the father of my unborn child. He's seventeen, I'm thirty-three. I was his teacher. I'd have killed myself by now if I was brave enough. (1)

Melody feels lonely and ashamed because she is pregnant by this illiterate Traveller boy: she wants her father to know that "he's not to blame" (23). She abandons her husband. Martin and his friend Mary, the children of two Traveller families engaged in a vicious feud play an important role in Melody's inner change.

Ryan uses the rhetoric of satire to present certain truths about the behaviour of Irish Travellers and settled people. Dustin Griffin argues that "In scholarly disputation, rhetoric is a means for detecting error" while "satirists [are] often concerned to explore a moral issue rather than to settle it" (41-42). Another part of satire is provocation and Estévez-Saá is right that Ryan's novel "is not exempt from controversy" (215). In a conversation printed at the end of his novel, Ryan recognises that some readers might be "upset by [some]thing I've written. But I'll just have to get over it, and so will they" (235-236). Ryan's use of the rhetoric of provocation in All We Shall Know may be misunderstood. According to Dustin Griffin, the rhetoric of provocation "often takes the form of paradox" (54). Satire takes the form of provocative paradox either because it seems absurd or because it 
challenges received opinion. Ryan uses abrupt allusiveness to provoke his readers and to expose or demolish foolish certainties. The following excerpt shows an example of satire as provocation:

A security guard followed us around the shop. Watch your man behind, Mary said to me [...] and said in a loud voice, Are you in love with me? And she waited patiently for the security guard's reply, but none came [...]. Are you in love with me, fine sir? The way you can't take your eyes off of me? Will we go way and get married, will we? And have gran little security guard children? And a group of meaty women stopped to watch the drama, and Mary turned to them and back to the security guard and said, More in your line keep an eye on that fuckin herd of buffaloes before they go on a stampede around the place [...].

And [...] in indignation [...] one of them said, Fuck you, you little bitch, and still the security guard stood his shaky ground [...].

What is it about me? I haven't even a bag with me to put stuff into. Why do you think I'm a thief? I never done notten in here ever before. (144-145; emphasis is mine)

Ryan provokes here because he is not only telling uncomfortable truths about the lives of Irish Traveller girls in small communities, but also showing the denigration that many of them suffer in public places. Furthermore, Ryan finds the sense of paradox useful to present shockingly heterodox opinions showing the difficult circumstances of Irish Travellers. Ryan's paradox is provocative not only because it seems absurd, but also because it challenges received wisdom. By repeating pejorative stereotypes about Travellers in the dialogue, Mary shows her indignation and implicitly denounces how certain settled characters' attitudes and comments about members of her community have an extremely negative impact on young Traveller girls' self-esteem, self-confidence and identity. Ryan's appreciation of paradox is challenging too and, in Griffin's sense, "against the orthodox" (55), but it is not simply a case of writing a paradoxical statement. It is in a broad sense satirical and oppositional. By acting provocatively, Mary not only exposes the legal authorities and their modus operandi; she also hints at Irish society's prejudice and discrimination of indigenous minorities and diverse immigrant groups. These marginalizing social attitudes also disturb the settled character Melody, who tries to empathise with Mary and, like her, is rejected by her small community because she wishes to live her own life.

Ryan addresses the damaging effects of internalizing feelings of inferiority and discrimination on Traveller girls like Mary. The psychological impact of longterm marginalization is counteracted by a mother-daughter type bond that develops between her and Melody, which gives both of them resilience. The end of the novel is very revealing of how important is this sense of mutual trust and understanding to recovering from long-term traumatic experiences and to facing daily challenges in dysfunctional contexts, such as Mary's Traveller halting site:

Travellers trust me now, and tell me things. A man from Ennis came to the door [...]. He'd heard I was a person who helped Travellers and he asked me would I see 
what I could do for his children. [...]. They tell me stories all the time, and I listen, and I don't pretend too much interest for fear they'd get nervous, or suspicious of my interest, and stop. (214; emphasis is mine)

Ryan courageously chooses a Traveller girl to call for confrontation of all the discriminatory stereotypes about her community, respect, honest dialogue and acceptance. The last paragraph is perhaps one of the most powerful moments of the whole book as the reader discovers that Melody hands over her newborn child to the young Travellers:

But nobody knows the whole of my story, nor will I ever tell them [...]. That the mother's name on my baby's birth certificate in MARY CROTHERY and that the father's name on my baby's certificate is MARTIN Toppy. That I left my baby in his basket [...], and she could read it, and so could Martin Toppy, and I was proud that they both could read it, because I had taught them, and had taught them well. (215)

Melody's newborn child is where he belongs. All We Shall Know is Ryan's most emotional and socially committed literary rendition of "the truth of things" (235) about Travellers, his attempt to illuminate the situation of Traveller women in Ireland and what other settled women like Melody can learn about themselves from them.

\section{IRISH TRAVELLER WOMEN IN FILM DOCUMENTARY}

The second part of this essay is intended to provide the context necessary to comprehend the social relevance of formal innovation in the aforementioned literary works featuring Irish traveller women. In 2005, British director Perry Ogden made the realist film Pavee Lackeen: The Traveller Girl (2005) which tells a story of marginalization, recreating the daily life and experiences of a real Traveller family, the Maughans, on the outskirts of Dublin. The film is very innovative, since Ogden recorded the family's actual life over a whole year and none of them is a professional actor. His attempt to produce an authentic document of their lives is innovative because, as Seán Crosson argues, it "eschews a conventional narrative, comprising instead simple narratives threads that reveal the considerable challenges the family members face" every day (185).

Ten-year-old Winnie Maughan has a very important role throughout Ogden's film and is revealed as intensely curious and innocent. In fact, all the Traveller girls with major roles in the fictional works under analysis resemble her. Like Josie in Carr's play, Victoria in Keegan's short story and Mary in Ryan's novel, Winnie is a victim of an unfair system that denies her proper schooling. When she fights with other children in the playing ground, because they call her names, Winnie is sent home for a few weeks. After this, she no longer attends school regularly. Pavee Lackeen describes how, outside school, there is little for a Traveller girl to do beyond helping out in the caravan, dyeing her hair, looking after their younger siblings, and hanging around with other Traveller children. Winnie, like Mary in Ryan's novel, 
is exposed on a daily basis to crime, drugs and violence; she is even discriminated against by young male members of her own group. Ogden show how Traveller girls are vulnerable and subject to the most insidious prejudice within and without their own community, yet institutions look in the other direction.

According to Seán Crosson, the film is unique because it is "made by a filmmaker coming from outside Ireland" and "tackles controversial issues which have rarely engaged indigenous directors" (185). The message is clear for Crosson: "if Irish society cannot treat her own indigenous minorities with respect how can it hope to embrace the diverse immigrant groups that increasingly make up the country[?]" (186). There is also something curious about Pavee Lackeen: beyond council officials and social workers, no other (settled) Irish people appear in the film. Crosson is right when he argues that this "appears sometimes overtly contrived" and it is indeed (186). This lack of inclusivity renders the film a biased representation of the Traveller Community in Ireland.

The second film under analysis is My Story (2009) by Irish director Jason Byrne. It is a documentary about the community worker, political activist and flamboyant playwright Rosaleen McDonagh, based on her reflections upon Byrne's adaptation of her play Stuck (2007), produced by the Projects Art Centre in Dublin. My Story presents the experience of McDonagh over recent decades, and considers what it means to be a Traveller woman who is a feminist, disabled and a playwright in Ireland.

Regarding film technique, Byrne uses the life-story approach to oral history and relies on the materiality of the sites to stimulate McDonagh's recollections. As Leydesdorff et al. argue, this approach "allows room for contradiction [...]. It gives the opportunity to explore the relations between personal and collective experience, by focusing on remembering and forgetting as cultural processes" (12). This film protocol allows McDonagh to dwell on multiple personal and collective issues, and on what is and is not said. The documentary technique aims neither to make the audience feel pity for McDonagh, nor to use her as an inspirational figure.

One of the most powerful moments in the film comes when McDonagh visits Trinity College Dublin, where she studied theology. Here, she acknowledges that attending university was transformative for her: she was already aware of issues relating to Traveller women's access to education and, here, she calls for women's right to education. Byrne's use of the storytelling protocol facilitates McDonagh's reflection upon the reasons why she, a Traveller and a woman, had to fight for her right to receive further education, craved it, and why she now writes for empowerment. Byrne's storytelling technique also asks why Irish Traveller women are denied the right to be educated like the rest of society and why it is necessary for McDonagh to make a conscious decision to support her Traveller roots, ethnicity and culture, and why all these are issues at all.

A second powerful moment in the documentary occurs when the playwright parks outside an institutional home in Dublin which was managed by nuns, and where $\mathrm{McD}$ onagh lived for over a decade. The storytelling technique uncovers that she was treated well, yet felt a huge sense of guilt for having forced her Traveller family to move from their rural halting site to Dublin, because they could not get 
the social services she needed in rural Ireland. McDonagh acknowledges that she felt privileged because other Traveller girls of her age did not have such a home, and that she only enjoyed advantages because she was disabled -this was her ticket to the privileges of settled society. At the end of the film, McDonagh gives a clear message: "I want to be recognised as a writer. I am not a victim. I am an independent, mobile, chic ethnic minority woman and this is a very powerful feeling". In my view, McDonagh's conception of writing as empowerment and a motor of social change for Irish Traveller women will be effected through their own self-representation and artistic efforts.

The last object of analysis here is I Am Traveller by director Kim Bartley (2016). The film features Irish actor, screenwriter, documentary film-maker and human rights activist John Connors, famous for playing pipe bomb maker Patrick Ward in the Irish crime drama Love/Hate. In Bartley's film, Connors, an Irish Traveller, embarks on a personal journey to tackle uncomfortable truths about racial stereotypes and Traveller identity. In terms of film technique, Bartley uses three main protocols -inclusivity, interviews and life storytelling- and thus treats all participants equally, be they settled or Traveller.

Regarding inclusivity, the film shows as full a range of participants as possible, many of whose stories conflict in terms of experience and interpretation. By asking the audience to listen to the stories of the "other", the film gauges people's ability to mature and perhaps challenge their own perceptions. A very good example of this is Connors' claim, around 11'45" into the film, that there is a problem with generalisation through stereotypes in the media and questions certain headlines. He interviews Paul Williams, an Irish media personality and writer on crime, about a horrendous attack suffered by a Traveller family in Cork in 2016. The viewer is provided with two different versions of the same event, while Byrne remains neutral: that of Williams (settled) and that of Connors (Traveller). Of course, they disagree about the flashy headlines used by the media and other issues: Connors claims that the news should have reported "a travelling gang", not "A Traveller gang", because the perpetrators of the crime were four settled people and three Travellers. Williams agrees that "to a degree it is society's fault but it is also Travellers' fault as a community group." Williams then asks Connors: "When are you going to march for the settled community's problems caused by drug dealers, rapists and criminals from your community and outside it?" The latter answers, "I can't take responsibility for things I can't control", such as criminal elements: "I take responsibility for things in my culture that need to change: education, suicide and social attainment".

There are other examples of inclusivity in I Am Traveller. Around the 39minute mark, Connors interviews a journalist who was a panellist on a popular TV programme back in 1995. He and Connors are watching a video record of that time, where the male panellist is arguing with a female panellist about Travellers' situation in Ireland a few decades earlier because she was expressing racist views regarding the Traveller community. After viewing the recorded excerpt, Connors listens to the panellist's arguments on how the situation has changed for Irish Travellers in the intervening 25 years. He makes it clear that things have changed little, because the system is still discriminatory towards this ethnic minority. 
As far as the third protocol is concerned, the use of the life story approach to oral history and reliance on the materiality of institutional sites to stimulate memory recollection, Connors engages in conversations with a young male Traveller whose caravan was set on fire a few months earlier, killing his younger brother. The third protocol shows not only the poor sanitary conditions in which his large family lived in a caravan in a halting site, but also how dangerous their cooking and heating facilities were. Worst of all, the viewer observes the post-traumatic effects of the accident and other traumatic experiences on one of the most vulnerable members of society, a young Traveller, who cannot attend school because he must take care of his family and earn a living.

In sum, these three protocols allow Connors to speak about the conditions of the Traveller community in Ireland. He wishes government would take responsibility for tackling lack of education, high suicide rates and poor social attainment. Bartley's documentary reveals that Irish Travellers, especially girls, feel constant discrimination, beginning with insults, such as "knacker" at school. The film's complete title, I Am a Traveller, not a Knacker, is very telling too for, as Connors explains, insulting words such as "knacker", used by settled Irish, make Irish Travellers feel angry, threatened, humiliated and self-loathing. These feelings of shame and rage have long-term effects upon Irish Travellers' psyche. This is why many Irish Travellers change their accent and behaviour when they seek a job in the settled community. In other words, they opt to deprive themselves of some of the most important traits of their identity to be accepted in society and earn a living.

Bartley's film also tackles other interesting issues regarding Irish Traveller women. Perhaps one of the most fascinating moments is Connors' interview with two women. They are described as being far more interested in education than their male counterparts, who are "more stuck in the past". Connors states that "women travellers have a more forward-thinking attitude than males, yet their main difficulty is that they do not receive enough support from their families"; he concludes that, if Traveller women have no right to education, their chances of finding a job are considerably reduced and they will never have opportunities for promotion, and thus for personal and professional development. This is why most Irish Travellers, male and female, are doomed to long-term unemployment, alcoholism or creating a family.

One of the main ideas that one draws from Bartley's three documentary protocols is that Travellers need a different mindset and lifestyle, and not to be enclosed, distanced. Settled people and Irish Travellers need to be better educated about each other; Travellers cannot be ignored, treated as less worthy or as though they do not even count. Unless Irish society addresses this, the stereotypes and misunderstandings will continue. At the end of the film, Connors, who is wealthy but, as Kitty Holland argues, "now back living in the Darndale halting site where he spent his childhood, remains angry at how many in the settled community treat Travellers" (2016a, n.p.).

The end of the film calls for support of young Travellers because at present, they are at a crossroads in terms of culture and identity. As Connors argues, many 
of the cultural trends and traditions of Irish Travellers have disappeared, and the younger generations need a secure status to define themselves. They need something on which they can pin their identity. The final message of the film is clear: real change will only occur when there is: 1) real and practical change within the Traveller community; 2) a progressive and more open recognition of Travellers' identity; and 3) a will on both sides to confront all the discriminatory stereotypes about the Traveller community. Bartley's three protocols help the viewer indirectly to reflect upon these issues.

\section{CONCLUSION}

This essay has explored cultural products in various genres that write Travellers into Irish history by using experimental forms and devoting special attention to gender issues. Irish writers Carr, Keegan, McDonagh and Ryan deploy innovative techniques of the satirical mode to carry out a social critique that is veiled, curious, provocative and inquiring. On the one hand, settled writers Carr, Keegan and Ryan address their irony and wit at biased uses of traditional folklore and stereotypes regarding Irish Travellers women in small rural communities to defame and marginalize them. They subtly subvert the negative social constructions that are usually associated with the Traveller community in general and Traveller women in particular in the literary and popular imagination. The experimental features of their satirical discourse and thematic interests show not only that they possess a highly developed aesthetic self-consciousness and fascination with folklore and the popular imagination, but also great respect and commitment to social justice. Ultimately, they make present the Irish Traveller community's strong sense of selfhood and identity linked to its roots and culture, and the significance of strong mother-daughter bonds within the community. On the other hand, McDonagh, an Irish Traveller, shows the need for profound change in the behaviour of both Irish Travellers and settled Irish in very witty, ironic and parodic terms. In doing so, this feminist, disabled playwright subverts many cultural constructions, writes for empowerment and with an unstinting commitment to defend her Traveller identity and ethnicity.

The narrative virtuosity, detached stance and multifaceted satire exploited by these four writers undermine traditional concerns and preconceptions, not only about the Irish Traveller community, its life, identity and culture, but also, more specifically, about Irish Traveller women's social roles, sense of motherhood and sexuality which hinder their self-confidence and self-actualization at present. Their stories' impact is rational and satirical, yet also emotional and tragic.

All three documentaries analysed here use various film protocols to make sharp social observations about the Traveller community in Ireland. Pavee Lackeen fails to use the inclusivity protocol, yet its interviews and realist situations interrogate and reflect profoundly upon themes as varied as Irish Traveller's experience of social discrimination, poor sanitary conditions, unequal access to social services and benefits, lack of education, bad marriages, dysfunctional families, childhood and community life, and women's dissent. My Story and I Am Traveller use all the three 
protocols -inclusivity, interviews and life storytelling-to tackle these issues in an indirect manner as well. They interrogate and reflect profoundly upon the dislocation of social relations within the Irish Traveller community, the post-traumatic and negative psychological effects of long-term and constant discrimination and marginalization, and gender and identity crisis. In sum, all these literary and filmic materials present a respectful and courageous treatment of conflictual issues affecting Irish Travellers in general and women in particular today. Their stories unmask, anatomize, and expose unpalatable truths about Irish Travellers' lives that need consideration: social inclusion, tolerance, equality of education and job opportunities, decent accommodation and sanitary conditions.

These writers and film-makers also show concern to lead their readers and viewers to recognise the strictures -social, political, religious and cultural-in Irish society, and the importance of accepting and preserving Irish Travellers' identity and culture for the well-being and coexistence of the younger generations. Their experimental methods and techniques help to mediate their Traveller characters' dysfunctional lives and to unveil this ethnic group, its traditions and culture. In this way, their works not only push for better treatment of Irish Travellers by the state, because its infrastructure is still discriminatory, but also attempt to disturb wider society's complacency.

All the works analysed here show that Irish Traveller women are still a distinct minority subject to the most insidious prejudice both within their small communities and in Irish society. The Traveller girls and teenagers who inhabit these literary and filmic stories open up a world of possibility and change for the other characters around them. The revelatory messages which come from this minority and marginalized youth lead the reader to contemplate the shortcomings of rural Irish society, and how they have changed very little in recent times, meaning that conflicts in private and public spheres remain commonplace.

This essay has tried to make clear the problematic nature of the artistic representation of an ethnic group by outsiders; a representation that is often troubled when the culture is so degraded and discriminated against. Inevitably, settled writers like Carr, Keegan or Ryan and film directors like Ogden, Byrne and Bartley are members of the oppressor class -the class by which discrimination is enacted. Creative works of the imagination can end up being supportive of the status quo if they are not overtly conscious of it. The Traveller community in Ireland must be allowed to represent itself or its diverse selves as we have seen in McDonagh's Mainstream, McDonagh's storytelling in Byrne's Rosaleen McDonagh and Connors in Bartley's I am Traveller. They all give a very personal and honest look at what it is like to be a Traveller in Ireland today. All these works show that the state's infrastructure is still discriminatory and that real, true change will come through Travellers' own self-representation and efforts.

All the main characters of the literary and filmic texts analysed here show that the younger generations of Irish Traveller women are furious and that righteous fury and their higher ambitions for themselves and their communities will bring change. Settled people like us, and institutions, must be careful not to get in the way of those movements, but to offer respect, tolerance and open-mindedness, and 
assistance in social community mapping only if requested. ${ }^{2}$ Ultimately, my reflections on Irish Traveller women highlight important cultural questions while situating all the works discussed as a means of returning Irish Travellers, both male and female, to their rightful place in history, and of asserting the social value of literature and film-making. In this sense, the essay has attempted to deconstruct some biased social constructions about Irish Travellers and to make us ponder what all of us do to contribute to such biased constructions pointed out by Lanters at the outset of this essay, and what we can all do to subvert them.

Reviews sent to author: 12 March 2019

Revised paper accepted for publication: 13 July 2019

${ }^{2}$ I am very much indebted to Irish poet Sarah Clancy for discussing and reflecting upon all the issues affecting Irish Travellers today with me. Her unstinting commitment to the Irish Traveller community in Galway and other parts in Ireland is most generous and valuable. 


\section{WORKS CITED}

Bartley, Kim. 2016. I am Traveller, Frontline Films for RTÉ.

Burnside, John. "All We Shall Know by Donal Ryan review -a modern-day Irish tragedy". The Guardian (22 September 2016). 18 December 2018. Web <https://www.theguardian.com/ books/2016/sep/22/all-we-shall-know-bydonalryan-review-a-modern-day-irish-tragedy>.

Byrne, Jason. 2009. Rosaleen McDonagh: My Story. Stuck Project Cube, Dublin.

Carr, Marina. Plays One: Low in the Dark? The Mai? Portia Coughlan? By the Bog of Cats..., Faber and Faber, 1999, pp. 247-341. Print.

Crosson, Seán. 2006. Irish Cinema 2005-Year in Review: Pavee Lackeen, Estudios Irlandeses, vol. 1: pp. 185-186. Print.

EstéveZ-SaÁ, Margarita. 2018. “Irish Studies Round the World: Review of Donal Ryan's All We Shall Know". Estudios Irlandeses, vol. 13. pp. 213-215. Web <https://www.estudiosirlandeses.org/ wp-content/uploads/2018/03/DEF.Round-the-World-Section.pdf>.

Fogarty, Anne. “Mother-Daughter Relationships in Contemporary Irish Women's Fiction”. Writing Mothers and Daughters: Renegotiating the Mother in Western European Narratives by Women, edited by Adalgisa Giorgio, Berghahn, 2002, pp. 85-118. Print.

Gibbons, Fiachra. "Life's a Terrible Torture That's Sent to Try Us". The Guardian. (10 February 2006). 18 June 2018. Web https://www.theguardian.com/film/2006/feb/10/1.

Griffin, Dustin. 1994. Satire: A Critical Reintroduction. Lexington, University Press of Kentucky. Print.

Holland, Kitty. "I am a Traveller, not a 'knacker" (18 March 2016a). The Irish Times. 18 June 2018. Web <https://www.irishtimes.com/life-and-style/people/i-am-a-traveller-not-aknacker-1.2577202>.

Holland, Kitty. "Pressure growing over discrimination against Travellers". The Irish Times (26 October 2016b). 18 June 2018. Web <https://www.irishtimes.com/news/socialaffairs/ pressure-growing-over-discrimination-against-travellers-1.2844305>.

Ingman, Heather. 2007. Twentieth-Century Fiction by Irish Women: Nation and Gender, Ashgate. Print.

Ingman, Heather. A History of the Irish Short Story, Cambridge University Press, 2009. Print.

Keegan, Claire. 2007. “The Forester's Daughter”, Walk the Blue Fields, Black Cat. Print.

Knight, Charles A. 2004. The Literature of Satire. Cambridge: Cambridge University Press. Print.

Lanters, José. "Beyond This World: Fantasy and Myth”. The 'Tinkers' in Irish Literature, Irish Academic Press, 2008, pp. 134-163. Print.

Leydesdorff, S. et al. 2004. 'Introduction' in Lacey Rogers, K.L. Leydesdorff, S. Dawson, G. Trauma: Life Stories of Survivors. New Brunswick: Transaction, pp. 1-9. Print.

McDonagh, Rosaleen. 2016. Mainstream. London: Bloomsbury Methuen Drama. Print.

Ní Dhuibhne, Éilís. "Give a Thing and Take it Back". Dublin Review of Books (5 Spring 2008). 21 January 2013. Web <http://www.drb.ie/essays/give-a-thing-and-take-it-back>.

Ó нAорна, Mícheál. 2016. 'Insubordinate Irish': Travellers in the Text. Manchester: Manchester University Press. Print.

Ogden, Perry. 2005. Pavee Lackeen: The Traveller Girl. An Lár Films. 
Patten, Eve. "Contemporary Irish Fiction". The Cambridge Companion to the Irish Novel, edited by J. Wilson Foster, Cambridge University Press, 2006, pp. 259-275. Print.

Ryan, Donal. 2016. All We Shall Know. London: Penguin. Print.

WaLshe, Eibhear. "Frank O’Connor's Lonely Voice: Dissent in the Modern Short Story”. Contemporary Debates on the Short Story, edited by Ibañez, J.R., Fernández, J.F. and Bretones, C.M. Peter Lang, 2007, pp. 107-127. Print.

Worcester, David. “The Art of Satire”, in Satire: Modern Essays in Criticism. Ed. R. Paulson. New Jersey: Prentice Hall, 1971, pp. 115-133. Print. 